\title{
MÄORI LAW AND HART: A BRIEF ANALYSIS
}

\author{
Mämari stephens*
}

This is an edited version of a seminar paper presented in the context of the LLB(Hons) programme. It provides a contemporary perspective of Mäori law from the standpoint of HLA Hart's theory of the union of primary and secondary rules.

\section{INTRODUCTION}

2001 is the fortieth anniversary of the publication of $\mathrm{H}$ L A Hart's landmark jurisprudential text The Concept of Law. ${ }^{1}$ This year also saw the release of the New Zealand Law Commission's long awaited report on Mäori custom and law. ${ }^{2}$ Hart would probably have called Mäori customary law a primitive or "pre-legal" system according to the criteria in The concept of Law. The warm reception of the Law Commission's report indicates that Hart's assumed perspective may be considered outdated. However, Hart remains a dominant figure on the New Zealand jurisprudential landscape, and in this paper his ideas are revisited with the benefits of a greater knowledge of the Mäori practice of law.

In The Concept of Law HLA Hart does not demonstrate what his notion of a primitive or pre-legal system actually looks like, or how it functions. Therefore his theory, as it stands, is inadequate for the examination of Mäori practice, and appears inadequate for the legal

* $\quad$ BA (Hons), MA (Distinction).

1 The Concept of Law (Clarendon Press, Oxford, 1961).

2 Mäori Custom and Values in Law, SP9 (New Zealand Law Commission, Wellington, 2001). 
analysis of any community. Mäori law is adequately reflected by Hart's legal system. Therefore, Hart's theory of law as the union of primary and secondary rules can be useful as a means of analysis, but his notion of the primitive system is perhaps fatally flawed and may be superfluous.

\section{HART'S PRIMITIVE SYSTEM}

Hart characterises a legal system as one that possesses both primary rules of obligation and secondary rules that enable the recognition, change and adjudication of those primary rules. ${ }^{3}$ He describes a system of rules as "pre-legal" or "primitive" if it merely contains primary rules without the all-important secondary rules. 4

In the first place, the rules by which the group lives will not form a system, but will simply be a set of separate standards, without any identifying or common mark...They will in this respect resemble our own rules of etiquette....[t]here will be no procedure for settling...doubt either by reference to an authoritative text or to an official whose declarations on this point are authoritative.

The closest Hart comes to describing what such a system would look like is when he notes that "only a small community closely knit by ties of kinship, common sentiment, and belief, and placed in a stable environment, could live successfully by a regime of unofficial rules". ${ }^{5}$ Only in Hart's endnotes does he acknowledge that few such societies have ever existed. ${ }^{6}$ He refers the reader to The Cheyenne Way and the other anthropological works of AS Diamond and E Hoebel, because, in his view, their work provides "study of the nearest

3 HLA Hart, The Concept of Law (2 ed, Oxford University Press, New York, 1997) 79-99.

4 Above $\mathrm{n} \mathrm{3,92.}$

5 Above n 3, 92.

6 Above n 3, 291. 
approximation to this state."7 Yet none of his sources describe small, kin-bound communities existing in stable environments. Instead they describe complex communities at the mercy of hostile and unstable environments, which calls into question Hart's usually careful use of language, and the attention he paid to what his sources actually described. Another problem is that the anthropological writing on which he relies adheres to theories that become dated. Hoebel was later to describe the Inuit as "one of the most genuinely primitive peoples known to anthropologists"; ${ }^{8}$ a statement ripe for challenge in the light of contemporary scholarship. If Hart exhibits some carelessness in his demonstration of the primitive or pre-legal, perhaps he was less willing to see the presence of his legal system in non-Western cultures. Waldron is confident Hart's primitive system is not to be read in terms of "modernist triumphalism": "He makes no assumption that a given society is better off with this change plus this adaptation than it would have been without either of them". ${ }^{9}$ However Hart does judge the primitive system - he defines it in terms of what it does not possess. He defines it by its defects. This is a modernist assumption.

Even on a brief reading there is little agreement between Hart and his sources on what may be a primitive, pre-legal system. Hart's theory of the union of primary and secondary rules is based on the emergence of such a union from the primitive system. But the prelegal is a chimera; easy to picture in the mind's eye, less easy to find in actual practice. The primitive system remains a theoretical

7 Hart, above n 3, 291. This comment is somewhat ironic, as the Cheyenne way is a detailed study of Cheyenne legal practices, not the description of a society that fits Hart's notion of primitive law at all. KN Llewellyn and EA Hoebel, The Cheyenne Way - Conflict and Case Law in Primitive Jurisprudence (University of Oklahoma Press, Norman, 1941).

8 EA Hoebel, The Law of Primitive Man (Harvard University Press, New York) 99.

9 J Waldron, "All we like sheep" (1999) 12 (1) Canadian Journal of Jurisprudence 169, 174. 
construct in The Concept of Law, a foil to the real star: Hart's legal system.

Despite the inadequacy of Hart's notion of the primitive system, his idea of the union of primary and secondary rules can be a useful tool of analysis of non-Western cultures. Mäori society offers possibilities for such legal analysis. Mäori practices may also serve to identify how difficult it is to define a system as "primitive" in the Hart sense.

\section{ISSUES IN ANALYSING MÄORI LAW}

Before analysing Mäori processes in the light of Hart's legal system, it is necessary to point out some of the complexities in analysing Mäori law. There is danger in using Western legal theory to analyse and judge a non-Western legal entity. Automatically, the Western idea becomes the frame of reference for discourse, undermining the worldview of the non-Western people.

The other danger in approaching the analysis of Mäori practices within Western discourse is in taking an extreme culturalist position. Culturalism itself is a useful means of criticism, as demonstrated by Moana Jackson, perhaps the most well-known culturalist commentator on New Zealand law. ${ }^{10}$ According to this perspective Maori law must be recognised within the mainstream legal system. An extreme culturalist position would be that Mäori law and institutions should not be analysed using Western tools of analysis because the cultural derivation of those tools vitiates such analysis.11 This position prevents the comparison of legal ideas between two worldviews.

10 See, for example, Moana Jackson "Criminality and the Exclusion of Mäori" (1990) 20 VUWLR 33

11 Cultural relativism may also be a useful term. For further (albeit in itself culturally weighted) discussion of the potential problems of extreme culturalism or cultural relativism in the discourse between Western and non-Western modes of thought in comparative legal history, see Ann Mayer Islam and Human Rights (Pinter Publishers, London, 1995) 4-11. 
Both culturalism and "Westernism" have probably contributed to some reluctance by modern legal scholars to analyse the form and function of Mäori law at all. As Chief Judge $E$ T Durie observed in 1994 "[t]here is no text or study that casts our knowledge of Mäori custom in jurisprudential terms."12 In response to Chief Judge Durie's observations, and with his further input, the Law Commission released the report entitled Mäori Custom and Values in New Zealand Law in March 2001.13 Intended as a practical guide, it offers a valuable distillation of Mäori customary concepts. The report accepts their definition as law without delving very deeply into exactly how such concepts function as law, or indeed what "law" is supposed to achieve in Mäori or New Zealand society. ${ }^{14}$ This report offers a useful starting point for further debate and exploration of Mäori law.

There have, of course, been many positivist assumptions about Mäori law, but this does not equate with analysis of the Mäori legal system using modern positivist legal theory. Perhaps Hart, or other modern theorists do have something to offer the study of Mäori practices. This

12 ET Durie "Custom Law: Address to the New Zealand Society for Legal and Social Philosophy" (1994) 24 VUWLR 325.

13 New Zealand Law Commission Mäori Custom and Values in New Zealand Law (NZLC SP9, Wellington, 2001).

14 The writers of the paper accept an anthropological definition of law, implicitly rejecting a positivist view. See Metge in New Zealand Law Commission Mäori Custom and Values in New Zealand Law (NZLC SP9, Wellington, 2001) 17-18. 
essay will use Hart's theory to analyse Mäori processes to see if we may gain anything by doing so; either a better understanding of Hart's theory or of Mäori society. ${ }^{15}$

\section{A MÄORI LEGAL SYSTEM}

Hart replaces the Austinian system of a general habit of obedience to orders backed by threats with two conditions that make up the legal system. ${ }^{16}$ The first condition consists of primary rules of behaviour that are considered valid according to an ultimate criterion of validity that must be generally obeyed. The second condition is made up of secondary rules of recognition (specifying the aforementioned ultimate criterion), change and adjudication that are effectively recognised as common public standards by the system's officials. In examining Mäori processes it is useful to identify how and if these conditions exist.

\section{A A Mäori Rule of Recognition}

Primitive "pre-legal" societies, according to Hart are characterised by uncertainty, stasis and inefficiency. In contrast legal systems are characterised by certainty, dynamism and efficiency. Uncertainty means that there is no mechanism for deciding the actual extent of a particular rule of obligation. There is no official or written text to refer to, leaving the actual edges of the law in

15 One final word of caution: earlier Western writers have already placed their own interpretations on the Mäori legal practices. Those Western perspectives and the customs have changed considerably over the past couple of centuries of contact. A discussion of Hart's theory and Mäori law in 2001 must also be interpreted within its own temporal context if it is to avoid a charge of essentialism on either topic. Please note the conscious use of the "historical present tense" in this essay. Most of the Mäori practices referred to here are spoken of in their pre-European or early colonial forms. The extent to which such institutions survive in contemporary New Zealand is worthy of much more discussion elsewhere.

16 HLA Hart The Concept of Law (2 ed, Oxford University Press, New York, 1997) 116 . 
doubt. ${ }^{17}$ This is rectified in a legal system by the introduction of a rule of recognition. This rule will specify the characteristics needed by a particular rule to be generally obeyed.

The concept of tikanga may fulfil the idea of a rule of recognition by identifying the ultimate criterion of validity needed to underpin a legal system. The Williams Dictionary defines tikanga as "rule, plan or method." It is a noun derived from the adjective "tika" meaning straight, direct, just, or fair. ${ }^{18}$ According to a recent paper presented by Professor Hirini Moko Mead "tikanga" embodies the following: 19

...a set of beliefs and practices associated with procedures to be followed in conducting the affairs of a group or an individual. These procedures, as established by precedents through time, are held to be ritually correct, are validated by usually more than one generation and are always subject to what a group or an individual is able to do...

Tikanga, according to Bishop Manuhuia Bennett, indicates the obligation to do things in the "tika" way. ${ }^{20}$ Tikanga contains within itself central values such as whanaungatanga, mana, tapu, utu, kaitiakitanga, mana tupuna, wairua and aroha. ${ }^{21}$ Such values were

17 Hart, above $\mathrm{n} 3$, 92. Much ink has been spent discussing the uncertainty of statute and Common Law, which continually evades easy categorisation and definition. Somehow this uncertainty does not seem to raise questions about possible primitivism in Hart's legal system.

18 HW Williams A Dictionary of the Mäori Language (Government Printer, Wellington, 1985) 216.

19 "The Nature of Tikanga" presented at Mai i te Ata Häpara Conference Wänanga - Raukawa, 11-13 August 2000 in New Zealand Law Commission Mäori Custom and Values in New Zealand Law (NZLC SP9, Wellington, 2001)16.

20 New Zealand Law Commission Mäori Custom and Values in New Zealand Law (NZLC SP9, Wellington, 2001) 16.

21 I roughly translate these terms as kinship, authority, ritual restrictions, equal return, guardianship, ancestral authority, spirituality, and love or yearning. 
common to different hapü and iwi, but were practised and interpreted according to the contextual situations of those groups. ${ }^{22}$

Tikanga and its use and practice characterise an internal point of view. This internal point of view is reflected in phrases often used today and in the past; "it is tikanga that [such and such] occur", "[a particular action] is /is not tikanga." Rituals of encounter, for example, were (and are) adjudged valid according to whether such a ritual satisfied the criteria provided by tikanga. Actions and other rules are judged by their compatibility with tikanga. In rules of succession the right of adopted children to succeed to rights in property can be traditionally determined to be against tikanga if an öhäkï, oral will, exists that contradicts or disallows those rights. ${ }^{23}$ The öhäkï itself must also satisfy criteria set by tikanga. ${ }^{24}$ The concept of tikanga thus provides the necessary principle or set of principles against which all rules may be measured. At the same time tikanga contains the content of those laws.

22 New Zealand Law Commission Mäori Custom and Values in New Zealand Law (NZLC SP9, Wellington, 2001) 4,28 Erueti in Richard Boast, Andrew Erueti, Doug McPhail and Norman F Smith Mäori Land Law (Butterworths Wellington 1999) 26 .

23 FOV Acheson "Adoption Amongs the Maoris of New Zealand" (1922) 4 ( $3^{\text {rd }}$ series) Journal of Comparative Legislation and International Law 60, 66. See also New Zealand Law Commission Mäori Custom and Values in New Zealand Law (NZLC SP9, Wellington, 2001) 118-120.

24 Such criteria included:

(1) It was the oral expression of the wishes and intentions of a Mäori before their death, regarding the disposal of their property.

(2) It had to be made in the presence of, and to be made known to near relatives.

For a full list of requirements see FOR Acheson, The Ancient Maori System of Land Tenure (thesis for the Jacob Joseph Scholarship, Victoria University College, 1913) 28. 
Hart's rule of recognition provides the criteria to assess the validity of other rules. ${ }^{25}$ Thus the Crimes Act 1961 provides the content of a criminal code, but the form of the Act is legislation as determined by the Queen in Parliament - mainstream New Zealand law's ultimate rule of recognition. The statutory order provides the criteria to assess the validity of the law. Mäori recognise marae protocols and öhäkï as law because they stem from tikanga; that which has been laid down by ancestors and ultimately by atua (gods). ${ }^{26}$ Tikanga provides Mäori with the criteria to assess which actions and rules are tikanga.

It could be argued that in the Mäori case the defect of uncertainty remains, for the external observer at least, because there is fluidity in how commentators and those who live by tikanga express them. Erueti, for example, states: "Tikanga are considered to have their source in a set of core values held by Mäori generally."27 Thus tikanga result from such values, whereas tikanga can be both the results of such values and the values themselves. ${ }^{28}$ This fluidity would surely invalidate tikanga as a rule of recognition according to Hart, even though his ultimate rule of recognition also exists subjectively in the "beliefs" of officials that they are bound by it. For those who perceive the internal aspect of tikanga fluidity presents no fatal uncertainty. This fluidity is difficult to pin down. It may be evidence of uncertainty in Mäori law, or it can counter the next flaw in Hart's notion of primitive law - stasis.

25 HLA Hart The Concept of Law (2 ed, Oxford University Press, New York, 1997) 116 .

26 Richard Boast, Andrew Erueti, Doug McPhail and Norman F Smith Mäori Land Law (Butterworths Wellington 1999) 25; New Zealand Law Commission Mäori Custom and Values in New Zealand Law (NZLC SP9, Wellington, 2001) 4, 15-17.

27 Erueti, above n 26, 25.

28 See also New Zealand Law Commission Mäori Custom and Values in New Zealand Law (NZLC SP9, Wellington, 2001) 28-40 for a fuller discussion of these values. 


\section{B Rules of change in Mäori law}

The defect of stasis in primitive law is the lack of an acknowledged process for changing any of the primary rules of obligation beyond simple change over time. Stasis is resolved in Hart's legal system by rules of change to introduce new primary rules and adapt those already in existence. For Hart, the simplest form of this rule empowers an individual or body to introduce new primary rules for the conduct of the life of the group and to eliminate old rules. 29

Recent commentators have observed that Mäori custom is not rigid, able instead to adapt to the changing requirements of the community, giving effect to a "practical jurisprudence."30 The exact mechanisms to incorporate such change into the life of the hapü or iwi are unclear. Clearly in pre-colonial times tribal hui were a vital institution whereby public opinion was delivered to the relevant chiefs. 31 The ability of Mäori communities to change customary practices was recognised by the courts early in the $20^{\text {th }}$ century in the case of Hineiti Rirerire $V$ Public Trustee of New Zealand ${ }^{32}$ quoting the Native Appellate Court in 1906. That Court noted that Mäori custom did not follow the English notion that custom must, in order to be called custom, have been in place since "time immemorial".

It may well be that this is a sound view of the law, and that [Mäori] as a race may have some internal power of self-government enabling the tribe or tribes by common consent to modify their customs, and that the customs

29 HLA Hart The Concept of Law (2 ed, Oxford University Press, New York, 1997) 95.

30 New Zealand Law Commission Mäori Custom and Values in New Zealand Law (NZLC SP9, Wellington, 2001) 5. See ET Durie (1994) 24 VUWLR 325, 327; Erueti above $\mathrm{n} 26,26$.

31 Elsdon Best The Mäori (Vol 1, The Polynesian Society, Wellington, 1925) $353-355,375$.

32 Hineiti Rirerire $v$ Public Trustee of New Zealand [1920] AC 198; (1919) NZPCC 1 PC 6. 
of such a race is not to be put on a level with the custom of an English borough...which must stand as it has always stood, seeing that there is no quasi-legislative internal authority which can modify it. (emphasis added)

Evidence for pre-European processes of rule-making is sketchy, nevertheless such rule creation and adaptation was done in hui called according to need. Polack recorded the following observation in the 1830s after some Europeans had repeatedly breached a tapu placed on the Whanganui River: ${ }^{33}$

The simple natives obeyed but the Europeans would not, and the chief discharged several muskets loaded with ball at the various boats as they passed...but at a conference that followed, it was carried unanimously and the motion seconded that, for the future, Europeans should not be shot at for such trifles.

Despite Polack's eurocentric interpretation, this piece does show that Mäori utilised group processes to alter the rules that they adhered to; they were not always bound irrevocably to their ancestral practices. ${ }^{34}$

Tribal and sub-tribal policy was forged by consensus, with all the chiefs and elders having a say. Whenever the group gathered, matters of policy were discussed and the best orators commanded great influence...oratory became crucial to the exercise of leadership.

The decisions that arose from such hui may be termed law. If legislation is merely the collective enactment of laws, then the Mäori in hui enact legislation and change and adapt those laws as necessary, providing such laws are valid according to tikanga. Certainly Mäori did not consider themselves bound by a static set of customs; they

33 J Polack New Zealand - Being a Narrative of Travels and Adventures (Vol 2, Whitcombe and Tombs, London, 1838) 255.

34 Anne Salmond Hui: A Study of Mäori Ceremonial Gatherings(2 ed, Reed Methuen, Auckland, 1976) 14. 
were fully able to change the rules by which they were bound, with only the condition that tikanga be maintained. ${ }^{35}$

Hart identifies uncertainty and stasis as central flaws in the primitive system but how can a primitive system be criticised for leaving its legal edges in doubt, yet also be criticised for having processes that are too rigid and unable to change? This inconsistency may perhaps be another flaw in Hart's primitive system.

\section{A Rule of Adjudication}

In Hart's primitive law, the lack of processes to make changes to or to define laws results in inefficiency. Resolution of any breaches of the rules will be left to the individuals and the groups that are able to pursue such resolution. ${ }^{36}$ Inefficiency must be countered by laws of adjudication, whereby individuals are empowered to judge when breaches have taken place and which procedure should be used to remedy breaches.

Were there officials in Mäori society empowered to judge breaches of rules and determine the resolution of such breaches? ${ }^{37}$

The Maoris had no all-powerful prince willing and able to enforce due obedience to their customs, but the customs were enforced by such means as existed, chief of these being the general opinion of the tribe, as expressed in meetings of the elders or through the mouths of the chiefs.

One group of people that may have been empowered to make such decisions were tohunga. Tohunga, translated as "skilled people" in Williams' Dictionary of the Mäori Language, were extremely important,

35 See New Zealand Law Commission Mäori Custom and Values in New Zealand Law (NZLC SP9, Wellington, 2001) $35 f$ regarding the role of rangatira in such communal decision making.

36 HLA Hart The Concept of Law (2 ed, Oxford University Press, New York, 1997) 93.

37 FOV Acheson The Ancient Mäori System of Land Tenure (Thesis for the Jacob Joseph Scholarship, Victoria University College, 1913) 3; see also Best (1925) 351; Wharepouri AULR (1994) 605. 


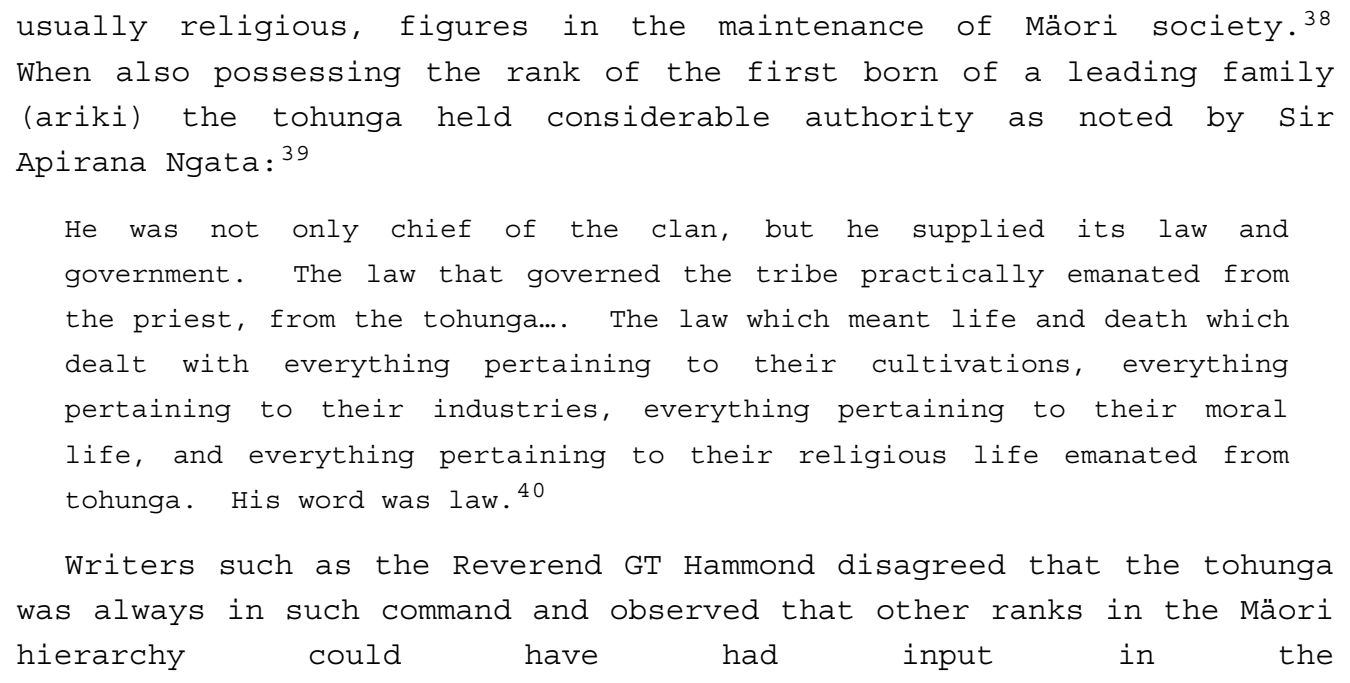

38 According to Shortland, every hapü contains at least one matakite (person with second sight) and several tohunga. E Shortland Traditions and Superstitions of the New Zealanders (Longman, Brown, Green, Longmans and Roberts, London, 1856) 106.

39 (July 19 1907) 139 NZPD 518.

40 It could be that Ngata here contradicts Acheson's theory negating "Strong Arm" rule in Mäori society discussed earlier in this paper. This quotation is included to illustrate that tohunga are seen by at least some commentators as individuals or officials responsible for ascertaining the laws of a given community. 
adjudication of laws. ${ }^{41}$ The fact that Mäori practices were not easily agreed upon by external observers indicates some complexity in Mäori processes that defies categorisation as "primitive".

Laws of adjudication must also outline the procedure by which breaches are identified and remedied. ${ }^{42}$ One such procedure might be the institution of tapu, at its broadest meaning: ritual restrictions placed on people, things and acts. ${ }^{43}$ One function of tohunga and other notables in hapü was to identify when to apply appropriate restrictions to people, things and activities or to identify that which had been rendered tapu. Breaches of tapu needed to be resolved in the interests of community welfare. ${ }^{4}$ Such resolution might be mediated through a tohunga, by placating the gods, or might be achieved through supernatural means beyond the control of any human agency. ${ }^{45}$

41 CMG Gudgeon, "The Tohunga Maori" (1895) 2, 16 JPS 63-91; T G Hammond, "The Tohunga Maori" (1908) 17, 67 JPS 163-165. Hammond includes other ranks such as Tumu Whakarae (supreme leader), Pou-Matua (third in rank) as well as the rangatira. That there has been ongoing disagreement as to the exact identity and position of such officials represents a continuing scholarly anxiety to tie down and define the institutions of Mäori society.

42 HLA Hart The Concept of Law (2 ed, Oxford University Press, New York, 1997) 96-97.

43 The definition of tapu needs far more space than I can give it here. It has many different meanings according to context. I concentrate on the ritual restriction because this "corrective and coherent power" of tapu comes closest to offering a process by which to determine breaches of tikanga. See HW Williams A Dictionary of the Mäori Language (Government Printer, Wellington, 1985) 385; New Zealand Law Commission Mäori Custom and Values in New Zealand Law (NZLC SP9, 36-38; S Mead, (ed) Customary concepts of the Maori: a source book for Maori Studies (Victoria University of Wellington, 1984) 68-106.

44 Durie, M in David Williams "He Aha te Tikanga Mäori?" (unpublished revised draft of Joseph Williams paper of the same name prepared for the New Zealand Law Commission Mäori Custom and Values in New Zealand Law (NZLC SP9, Wellington, 2001) 37.

45 Best in S Mead, (ed) Customary concepts of the Maori: a source book for Maori Studies (Victoria University of Wellington, 1984) 91. Note that tapu 


\section{CONCLUSION}

Mäori legal processes operate at a level over and above mere "etiquette" or primary obligations lacking an accompanying system. Tikanga Mäori decides what is and is not valid practice. Mäori also have processes by which laws may be altered and adapted to circumstances as required. Mäori social hierarchy includes figures with the authority to identify when breaches of primary obligations occur, and to decide what earthly action must take place to rectify such a breach. The Mäori system of tapu or imposing ritual restrictions on objects, people and places ensures that tikanga is observed.

Hart's theoretical construct of the primitive system does not reflect actual Mäori processes and it is difficult to imagine a culture that would reflect that construct. Therefore, its usefulness as an explanation of Mäori processes is questionable. If the label of "primitive" could be dropped and its application widened, the construct may retain some usefulness as a theoretical model with which to identify theoretical deficiencies in the legal practices of any society. Hart's notion of the legal system, on the other hand, throws new light on how Mäori ordered social and cultural life, and that investigation deserves more space than I can give it here. The idea of the primitive, pre-legal system lacks definition, and is a redundant mirage that vanishes on closer inspection.

This year is the fortieth anniversary of the concept of Law and belatedly time to acknowledge, with the release of the Law Commission's report and other similar works, the complexity of traditional Mäori legal practices. If Hart's primitive, pre-legal system is to survive as a theoretical construct it must be altered to make it more accurate, relevant and useful. If that alteration is not possible, the idea it should perhaps be dispensed with altogether.

must always be considered in relationship to the concept of noa: that which is ritually unrestricted. 
